\title{
ANALISIS VARIASI HARGA DAN INTEGRASI PASAR VERTIKAL CABAI MERAH DI KABUPATEN GAYO LUES
}

\author{
(Analysis Of Price Variation And Vertical Market Integration Of Red Chili In Gayo Lues \\ District)
}

\author{
Wan jumiana ${ }^{1}$, Azhar $^{1}$, Edy Marsudi $^{1 *}$, \\ ${ }^{1}$ Program Studi Agribisnis, Fakultas Pertanian, Universitas Syiah Kuala
}

\begin{abstract}
Abstrak. Cabai merah (Capsicum annum L.) adalah salah satu jenis sayuran yang cukup strategis untuk dibudidayakan di Kabupaten Gayo Lues. Siklus produksinya yang bersifat musiman menyebabkan produksinya terus berfluktuatif. Hal tesebut dapat mempengaruhi perubahan harga yang cendrung berfluktuasi sehingga menimbulkan kecurigaan adanya permainan harga dalam proses pemasarannya. Penelitian ini bertujuan untuk mengetahui variasi harga cabai merah di tingkat petani dan pedagang pengecer serta mengetahui integrasi pasar vertikal cabai merah di Kabupaten Gayo Lues yang terjadi antara petani dan pedagang pengecer dalam jangka pendek dan jangka panjang. Metode penelitian adalah menggunakan analisis Koefisien variasi untuk mengetahui tingkat variasi harga dan dengan pendekatan Kointegrasi Johansen dan Vector Error Corection Model (VECM) untuk mengetahui integrasi pasar vertikal. Data yang digunakan adalah data sekunder kuantitatif berupa harga rata-rata bulanan selama empat tahun (tahun 2014 - tahun 2017). Hasil penelitian adalah variasi harga cabai merah di tingkat petani dan pengecer adalah tinggi dan tidak stabil berdasarkan kriteria Kemendag yaitu dengan nilai rata-rata koefisen variasi sebesar $15,34 \%$ di tingkat petani dan 11,64\% di tingkat pengecer. Hasil uji kointegrasi Johansen harga di tingkat petani dan pengecer terdapat hubungan kointegrasi jangka panjang. Berdasarkan hasil estimasi hubungan integrasi jangka panjang dan jangka pendek menggunakan uji VECM, menunjukkan integrasi pasar vertikal cabai merah di Kabupaten Gayo Lues di tingkat petani dan pedagang pengecer terintegrasi masih relatif lemah.
\end{abstract}

Kata kunci: Variasi harga, Koefisien variasi, Integrasi pasar, VECM

Abstract. The red chili (Capsicum annum L.) is one of vegetables that is strategic enough to be cultivated in Gayo Lues Regency. Its seasonal production cycle causes its production to continue to fluctuate. This can affect price changes that tend to fluctuate, thus raising the suspicion of a price game in the marketing process. This study aims to determine the variation of the price of red peppers at the level of farmers and retailers and to know the integration of red chili vertical market in Gayo Lues Regency that occurred between farmers and retailers in the short and long term. The research method is to use the variation coefficient analysis to determine the level of price variation and with the Johansen Cointegration Approach and the Vector Error Corection Model (VECM) to know the vertical market integration. The data used is quantitative secondary data in the form of average monthly price for four years (year 2014 - year 2017). The result of this research is variation of price of red chili at farmer level and retailer is high and unstable based on Kemendag criterion that is with average value of coefficient of variation $15,34 \%$ at farmer level and $11,64 \%$ at retailer level. Johansen's cointegration test results at the farmers and retailer levels have long term cointegration relationships. Based on the estimation of long-term and short-term integration relationships using the VECM test, it shows the vertical market integration of red pepper in Gayo Lues District at the level of integrated farmers and retailers is still relatively weak.

Keywords: Price variation, Coefficient of variation, Market integration, VECM

\section{PENDAHULUAN}

Cabai merah (Capsicum annum L.) merupakan jenis sayuran yang strategis untuk dibudidayakan di daerah dataran tinggi maupun dataran rendah. Kebutuhan akan cabai merah terjadi secara terus menerus sepanjang tahun karena cabai merupakan sayuran yang menjadi kebutuhan pokok masyarakat Indonesia. Cabai merah adalah tanaman sayuran yang bersifat musiman sehingga pada musim tertentu, harga cabai merah mengalami kenaikan yang cukup

*Corresponding author: edymarsudi@unsyiah.ac.id 
signifikan dan pada suatu waktu mengalami penurunan yang sangat drastis. Ketidakpastian harga seperti ini disebut sebagai fluktuasi harga.

Menurut Simatupang (1999), bahwa fluktuasi harga sering dimanfaatkan para pedagang perantara untuk tetap mendapatkan untuk yang maksimal meskipun harga yang di bayarkan kepada petani relatif rendah. Dalam hal ini terdapat kesenjangan informasi harga di tingkat produsen sehingga besarnya perubahan harga dari pasar konsumen tidak langsung di transmisikan ke petani. Jika terjadi kenaikan harga di tingkat konsumen maka tidak diteruskan secara cepat dan sempurna ke tingkat petani, begitu pula sebaliknya. Prilaku pasar seperti itu mengakibatkan distribusi cabai merah tidak merata dan keuntungan lebih banyak dinikmati oleh pedagang perantara, dengan harga yang diterima petani relatif lebih rendah. Mencegah terjadinya asimetris informasi tersebut, ketersediaan informasi pasar yang akurat dan berkelanjutan mutlak diperlukan. Jika pedagang pengecer dan petani sebagai produsen memiliki informasi pasar yang akurat, maka perubahan harga dapat segera direspon oleh para pelaku pasar sehingga pengambilan keputusan dalam penetapan harga dapat dilakukan secara cepat dan tepat, sehing akan menciptakan pasar yang terintegrasi (FAO,et al, dalam Nuraeni,et al, 2015).

Manfaat integrasi pasar bagi petani dan pelaku pasar lainnya adalah supaya tidak ada pihak yang dirugikan terutama petani dan konsumen. Jika suatu pasar terintegrasi dengan baik maka tingkat kerugian di pihak petani dapat diminimalisir dan dapat mengurangi tindakan menyimpang dari pihak pedagang perantara. Pasar di tingkat petani dan pengecer dikatakan telah terintegrasi dengan baik jika informasi mengenai setiap perubahan harga cabai merah di tingkat konsumen dapat tersalur dengan cepat dan diikuti oleh perubahan harga di tingkat petani. Dengan demikian diharapkan dapat memberikan keuntungan yang adil bagi setiap pihak yang terlibat dalam proses pemasaran cabai merah (Nuraeni et al, 2015).

Kabupaten Gayo Lues merupakan salah satu Kabupaten yang ada di Aceh yang menjadi sentra produksi cabai merah. Daerah ini cukup potensial untuk dikembangkan tanaman cabai merah. Dengan keunggulan kompetitif yang dimiliki diharapkan mampu meningkatkan pendapatan usahatani cabai dengan nilai ekonominya yang tinggi. Sehingga dalam proses pengembangan usaha budidaya cabai merah sangat penting untuk di perhatikan mengenai produksi dan kestabilan harga. Produksi cabai merah di Kabupaten Gayo Lues cenderung berfluktuatif begitu juga dengan luas tanam dan luas panennya. Hal ini ditunjukkan oleh perkembangan data luas tanam, Luas panen dan produksi cabai merah di Kabupaten Gayo Lues Menurut BPS (2017), produksi cabai merah terus saja berfluktuatif begitu pula dengan luas tanam cabai merah hampir tidak meningkat. Produksi terbanyak cabai merah terjadi pada tahun 2015 sebanyak 6240 ton. Produksi ini meningkat dari tahun 2014 yang sebasar 4660 ton. Namun pada tahun 2016 produksinya mengalami penurunan meskipun luas tanamnya mengalami peningkatan sebesar $5 \mathrm{Ha}$. Namun demikian, dibandingkan dengan sayuran lainnya cabai merah merupakan sayuran yang memiliki produksi tertinggi dibandingkan dengan sayuran lainnya. Rata-rata produksi cabai merah 49.950 kuintal dalam kurun waktu enam tahun terakhir, hal ini disebabkan karena cabai merah memiliki keunggulan kompetitif dibandingkan sayuran lainnya. Dari data tersebut dapat diketahui bahwa cabai merah merupakan tanaman sayuran yang menjadi salah satu sumber mata pencarian masyarakat tani di Kabupaten Gayo Lues. Sehingga pemasarannya menjadi hal yang perlu mendapatkan perhatian dari berbagai pihak.

Sifat cabai yang musiman menyebabkan harganya juga bervariasi. Variasi harga tersebut membentuk pola pergerakan harga yang berfluktuasi secara teratur yang terjadi di setiap tahunnya. Kecenderungan harga cabai merah yang berfluktuasi tesebut terjadi hampir sepanjang tahun dan membuat petani dan konsumen resah atas ketidakpastian harga cabai, akan

Analisis Variasi Harga dan Integrasi Pasar Vertikal Cabai Merah di Kabupaten Gayo Lues 
tetapi belum adanya penanganan yang tepat dari pemerintah dalam mengatasi permasalahan harga yang berfluktuasi tersebut. Adapun perkembangan harga cabai merah di tingkat petani (Prices at farmers) dapat dilihat pada gambar berikut:

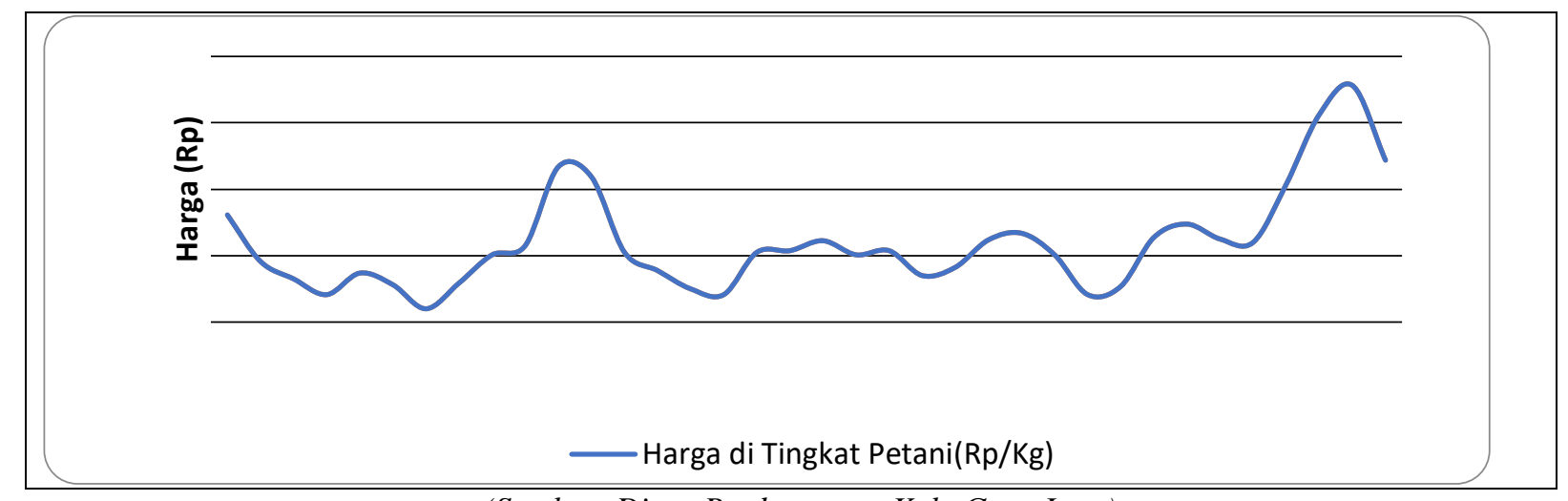

(Sumber: Dinas Perdagangan Kab. Gayo Lues)

Gambar 1. Perkembangan Harga Rata-rata Bulanan Cabai Merah di Tingkat Petani di Kabupaten Gayo Lues

Gambar 1. menjelaskan bahwa harga cabai merah di tingkat petani (PF) di Gayo Lues beberapa tahun trakhir cenderung berfluktuasi. Bagi masyarakat sebagai petani cabai, untuk mengusahakan cabai dengan kualitas yang bagus bukanlah hal yang mudah, karena cabai merupakan tanaman yang membutuhkan perawatan secara intensif untuk memperoleh hasil produksi yang maksimal. Hal tersebut sejalan dengan yang di kemukakan oleh Hasyim (2017), bahwa harga cabai merah di pasaran Kabupaten Gayo Lues (Galus) tidak stabil bahkan pernah mengalami penurunan hingga pada titik terendah yakni $\mathrm{Rp} 2.000 / \mathrm{Kg}$ padahal sebelumnya pernah mencapai $\mathrm{Rp} 80.000 / \mathrm{Kg}$. Kondisi itu membuat para petani memilih membiarkan cabai masak di batang, bahkan membusuk tanpa dipanen, karena harga jual tidak sesuai lagi dengan ongkos produksi. Turunnya harga cabai diduga adanya permainan spekulan. Tujuan dilaksanakan penelitian ini adalah untuk mengetahui variasi harga cabai merah yang terjadi di antara petani dan pengecer di Kabupaten Gayo Lues serta untuk mengetahui integrasi pasar vertikal cabai merah di Kabupaten Gayo Lues yang terjadi di antara petani dan pengecer dalam jangka pendek dan jangka panjang.

\section{Lokasi dan Waktu Penelitian}

\section{METODE PENELITIAN}

Lokasi penelitian ini dilaksanakan di Kabupaten Gayo Lues. Penentuan lokasi sampel dilakukan dengan metode purposive sampling (secara sengaja) dengan pertimbangan Kabupaten Gayo Lues adalah salah satu daerah yang menjadi sentra produksi komoditas cabai merah di Provinsi Aceh dan cabai merah merupakan tanaman sayuran yang paling banyak dibudidayakan di Gayo Lues. Penelitian ini dilaksanakan pada rentang bulan Maret -April 2018.

\section{Objek dan Ruang Lingkup Penelitian}

Objek penelitian ini adalah cabai merah dengan ruang lingkup penelitian hanya sebatas menganalisis data sekunder dalam bentuk kuantitatif yakni harga cabai merah di tingkat petani dan pedagang pengecer meliputi analisis variasi harga dan integrasi pasar vertikal cabai merah di Gayo Lues yang terjadi antara pasar di tingkat petani dan di pedagang pengecer.

\section{Jenis dan Sumber Data}


Data yang digunakan dalam penelitian ini merupakan data sekunder yang terdiri dari data harga jual cabai merah yakni harga rata-rata bulanan di tingkat petani dan pedagang pengecer selama kurun waktu empat tahun (time serries data) periode Januari 2014 hingga Desember 2017, serta kajian literatur yang diperoleh dari studi pustaka dan dari beberapa instansi terkait seperti Badan Pusat Statistik, Dinas Perindustrian dan Perdagangan Gayo Lues serta Balai Pengkajian Teknologi Pertanian Aceh (BPTP Aceh).

\section{Model Analisis}

\section{Analisis Variasi Harga}

Variabel yang digunakan adalah harga cabai merah di tingkat petani pada sentra produksi Kabupaten Gayo Lues dan eceran pada pasar eceran di Gayo Lues. Menganalisis variasi harga cabai merah dilakukan dengan menggunakan koefisien variasi. Koefisien variasi adalah ukuran penyebaran nilai yang memakai standar deviasi relatif terhadap nilai rata-rata data yang dinyatakan dalam persentase (Suharyadi \& Purwanto, 2003). Rumus yang digunakan untuk menganalisisnya adalah sebagai berikut:

$$
\text { Koefisien Variasi }(\mathrm{KV})=\frac{\text { Standar Deviasi }}{\text { Rata-rata }} \times 100 \%
$$

Koefisien variasi dari data harga secara runtun waktu menggambarkan fluktuasi (simpangan terhadap rata-rata) yang digunakan untuk mengetahui stabilitas harga suatu komoditas. Semakin kecil nilai koefisien variasi dapat ditarik kesimpulan bahwa harga stabil atau fluktuasi harganya relatif rendah (Rachman,2005). Harga di suatu kota/provinsi dikatakan stabil apabila nilai koefisien variasi harganya berada pada kisaran 5-9\% (Kemendag, 2010). Jika nilai koefisien variasi lebih dari $9 \%$ mengindikasikan harga berfluktuasi tinggi dan tidak stabil.

\section{Analisis Integrasi Pasar}

Untuk melihat adanya hubungan integrasi pasar vertikal cabai merah di Gayo Lues dilakukan tahapan pengujian yang berupa kointegrasi Johansen dan koreksi kesalahan (Error Correction Model). Data yang sudah stationer pada tingkat yang sama maka dapat dilakukan uji kointegrasi Johansen Test, akan tetapi apabila data tidak stationer pada derajat yang sama maka dilakukan tahap pendiferensiasian dan uji ECM juga dapat dilakukan meskipun nonstationer pada derajat yang sama. Uji selanjutnya adalah Engel Granger test atau lebih dikenal dengan modelnya Error Corection Model (ECM) untuk melihat pengaruh dalam jangka panjang. Hubungan dalam jangka pendek dapat dilihat melalui Granger Causality Test, yang besarnya dapat dilihat melalui persamaan yang terbentuk (Widadie dan Sutanto, 2012)

\section{Uji Stasioneritas Data (Uji Augmented Dickey Fuller)}

Dalam melakukan uji kestasioneran data penelitian ini menggunakan taraf kepercayaan 5\% (Gujarati, 2004). Pada penelitian ini kestasioneran data dianalisis dengan uji Augmented Dickey Fuller Test (ADF) dengan menggunakan persamaan sebagai berikut:

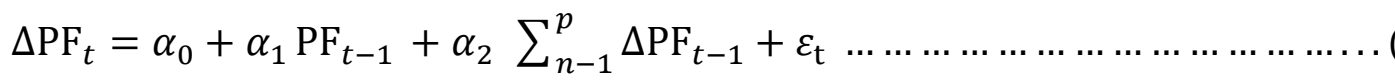

Keterangan:

$\alpha_{0} \alpha_{1}, \alpha_{2}=$ koefisien,

$\mathrm{PF}_{\mathrm{t}}=$ Harga cabai merah di tingkat petani pada periode ke- $t(\mathrm{Rp} / \mathrm{Kg})$

$\mathrm{PF}_{\mathrm{t}-1}=$ Harga cabai merah di tingkat petani pada periode sebelum ke- $t(\mathrm{Rp} / \mathrm{Kg})$

$\varepsilon_{\mathrm{t}}=$ Residual/error pada periode ke- $t$

Apabila data tidak stasioner pada tahap level maka selanjutnya distasionerkan melalui proses pendeferensiasian. Kriteria pengujian hipotesis yang digunakan adalah sebagai berikut:

$\mathrm{H}_{0}(\mathrm{~d}=1)=$ ADF hitung > nilai kritis mengandung arti bahwa data time series tidak stasioner, 
$\mathrm{H}_{\mathrm{a}}(\mathrm{d}<1)=$ ADF hitung $<$ nilai kritis mengandung arti bahwa data time series sudah stasioner.

\section{Uji Lag Optimal}

Dalam estimasi VECM memerlukan panjang lag yang digunakan. Untuk mengetahui lag yang akan digunakan maka julamh lag dapat ditentukan berdasarkan kriteria model Schwarz Information Criterion (SC), Akaike Information Criterion (AIC), Final Prediction Error (FPE),), maupun dengan Hannan Quinnon (HQ). Pengujian panjang lag optimal penting untuk dilakukan guna menghilangkan masalah autokorelasi dalam sistem melakukan uji VECM (Basuki, 2016 ).

\section{Uji Kointegrasi Johansen}

Uji kointegrasi merupakan langkah pengujian yang bertujuan untuk melihat hubungan keterpaduan suatu pasar dalam jangka panjang. Pada umumnya integrasi pasar yang terjadi dalam jangka panjang akan mempengaruhi integrasi pasar dalam jangka pendek. Jika bilai yang dihasilkan menunjukkan hubungna integrasi maka dapat di jelaskan bahwa variabel- variabel tersebut memiliki hubungan yang terintegrasi (Basuki, 2016). Dalam tahapan pengujian hipotesis ini menggunakan pendekatan nilai trace statistik. Persamaannya adalah sebagai berikut:

$\mathrm{Q}_{\text {trace }}=-\mathrm{T} \sum_{i=k+1}^{n} \ln (1-\alpha \mathrm{i})$

$\mathrm{Q}_{\max }(\mathrm{r}, \mathrm{r}+1) \ldots \mathrm{n}-1=-\mathrm{T} \ln \left(1-\mathrm{Q}_{\mathrm{r}+1}\right)$.

Keterangan:

$Q=$ trace, max statistik

$\mathrm{T}=$ jumlah observasi yang digunakan

$\mathrm{r}=$ jumlah vector dari vector pada hipotesis nol

$\alpha \mathrm{i}=$ nilai eigenvalue

Hipotesis nol yang digunakan pada Qtrace dan Qmax jika $\left(\mathrm{H}_{0}: \mathrm{r} \leq 0\right)$, artinya tidak terdapat hubungan kointegrasi. Atau paling banyak terdapat satu persamaan kointegrasi $\left(\mathrm{H}_{0}: \mathrm{r}\right.$ $\leq \mathrm{n}-1)$ maka $\mathrm{H}_{0}$ ditolak dan artinya terdapaat hubungan kointegrasi. Dengan kriteria pengujian berdasarkan hasil uji yang di dapat pada tabel uji Johansen sebagai berikut:

Ho = Data tidak terkointegrasi (Jika trace statistic dan max statistic < critical value 5\%)

$\mathrm{Ha}=$ Data terkointegrasi (Jika trace statistic dan max statistic > critical value $5 \%$ ).

\section{Uji Kausalitas Granger}

Tahapan pengujian kausalitas Granger dilakukan untuk mengetahui hubungan interaksi antar variabel di dalam lag tertentu selama pengujian lag. Prinsip dasar dari pengujian Granger pada penelitian ini adalah untuk menjelaskan hubungan antara harga jual cabai merah di tingkat petani dan pedagang pengecer. Dalam penelitian ini, pengujian mengenai kausalitas Granger hanya dilakukan dengan membandingkan nilai probabilitas dengan alfa yang digunakaan. Taraf keyakinan (alfa) yang digunakan sebesar 5\%, maka a $=0,05$. Jika p-value $>$ a, maka tidak terdapat hubungan kausalitas di dalamnya dan jika p-value $<$ a, maka terdapat hubungan kausalitas di dalamnya.

\section{Uji Vector Error Correction Model (VECM)}

Uji VECM merupakan tahapan pengujian yang digunakan untuk menjelaskan hubungan integrasi jangka pendek dan jangka panjang. VECM mengukur bagaimana penyimpangan harga dapat kembali pada keadaan keseimbangan (Hendy dan Juselius, 2000).. Model VECM dalam penelitian ini adalah sebagai berikut: 


$$
\Delta \mathrm{PF}_{\mathrm{t}}=\alpha_{0}+\alpha_{1} \mathrm{PF}_{t-1}+\sum_{i=1}^{p} \alpha_{2} \Delta \mathrm{PR}_{t-1}+\varepsilon_{\mathrm{t}}
$$

Keterangan:

$\alpha_{0} \alpha_{1}, \alpha_{2}=$ koefisien,

$\mathrm{PF}_{\mathrm{t}}=$ Harga cabai merah di tingkat petani pada periode ke- $t(\mathrm{Rp} / \mathrm{Kg})$

$\mathrm{PF}_{\mathrm{t}-1}=$ Harga cabai merah di tingkat petani pada periode sebelumnya $(\mathrm{Rp} / \mathrm{Kg})$

$\mathrm{PR}_{\mathrm{t}-1}=$ Harga cabai merah di tingkat pedagang pengecer pada periode sebelumnya $(\mathrm{Rp} / \mathrm{Kg})$

$\varepsilon_{\mathrm{t}}=$ Residual/error

$\mathrm{p}=$ Panjang $\operatorname{Lag}$

$\mathrm{t}=$ Trend waktu

\section{Variasi Harga}

\section{HASIL PENELITIAN DAN PEMBAHASAN}

Komoditas hortikultura dari jenis sayuran khususnya cabai merah merupakan produk yang paling sering mengalami fenomena harga yang berfluktuasi karena permintaannya terjadi secara terus-menerus sepanjang tahun. Namun pola produksinya yang bersifat musiman menjadi faktor utama penentu harga dari komoditas tersebut. Terkait dengan hal ini, maka analisis variasi harga menjadi hal penting dalam merumuskan kebijakan stabilisasi harga dan peningkatan produksi cabai merah serta membuat peramalan harga cabai merah ke depannya. Selain itu, analisis harga juga sering digunakan untuk menganalisis perilaku harga dan peubahpeubah yang terkait. Sebagaimana untuk mengetahui trend (kecenderungan), siklus, atau stabilitas dari harga suatu komoditas pada rentang waktu tertentu, maka penggunaan analisis harga menjadi hal penting yang dapat mengetahui hal tersebut (Santika,2008).

Produksinya yang bersifat musiman disebabkan karena cabai merah merupakan tanaman yang sangat rentan terhadap penyakit, khususnya pada saat cuaca ekstrim, sehingga harga cabai merah berfluktuasi. Pada kenyataannya harga cabai merah yang berfluktuasi ini disebabkan oleh dua alasan, yaitu naik turunnya penawaran (seperti keputusan produksi usaha tani, cuaca, hama dan penyakit dan luas areal panen), sementara permintaan cendrung meningkat dan adanya sistem penentuan harga yang secara sepihak oleh pedagang perantara. Penentuan secara sepihak ini adalah sistem penentuan harga yang sudah ditetapkan oleh pedagang perantara terhadap harga beli cabai merah dari petani. Dalam penentuan harga beli cabai merah di Gayo Lues, petani bertindak sebagai penerima harga (price taker) sedangkan pedagang perantara betindak sebagai penentu harga (price maker). Informasi harga merupakan salah satu komponen penting dalam informasi pasar, yang sangat diperlukan terutama oleh petani sebagai produsen. Secara umum pembahasan tentang harga cabai merah, pembentukan harga dan variasinya di tentukan oleh faktor utama yaitu tempat, struktur pasar dan waktu.

\section{Variasi Harga Menurut Tempat}

Pada tahun 2016 harga cabai merah mengalami kenaikan yang sangat fantastis, karena pada tahun-tahun sebelumnya belum pernah mengalami kenaikan harga yang sampai pada titik tersebut. Pergerakan harga konsumen yang dicapai pada tahun tersebut adalah mencapai kisaran harga Rp.20.000,00/Kg hingga Rp.90.000,00/Kg. Adapun perbedaan harga antar daerah yang disajikan pada gambar berikut: 


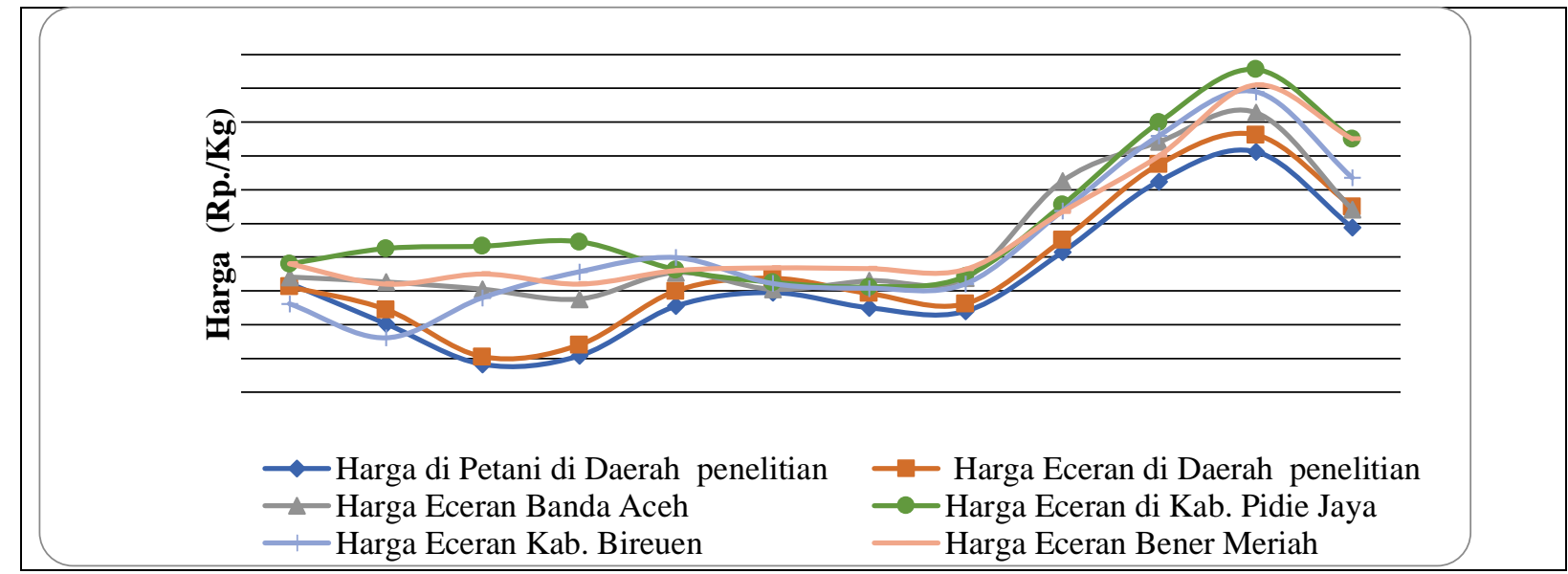

Sumber : Dinas Perdagangan Kab. Gayo Lues dan BPTP Aceh (2018), data diolah

Gambar 2. Perkembangan Harga Cabai Merah di Daerah Penelitian dan Beberapa Daerah Lain yang Menjadi Centra Produksi Maupun Daerah Tujuan Pemasaran Cabai Merah dari Gayo Lues Tahun 2016

Gambar 2. menunjukkan bahwa pada bulan Januari hingga April kisaran harga konsumen di daerah penelitian yang dicapai yaitu dibawah $\mathrm{Rp} 30.000,00 / \mathrm{Kg}$ sedangkan di daerah lain kisaran harganya mencapai Rp 30.000,00/Kg hingga Rp 40.000,00/Kg. Namun pada bulan Mei hingga Agustus harga di daerah penelitian dan daerah lainnya mengalami pergerakan yang sama. Pada bulan September harga mengalami kenaikan yang cukup signifikan yaitu dari rata-rata $\mathrm{Rp} 40.000,00 / \mathrm{Kg}$ hingga mencapai rata-rata tertinggi $\mathrm{Rp} 90.000,00 / \mathrm{Kg}$ dan menjelang awal tahun kembali mengalami penurunan. Meskipun demikian tetap saja harga cabai merah di daerah penelitian selalu di bawah rata-rata harga yang ada pada daerah lainnya.

Jika dibandingkan dengan daerah sentra produksi lainnya harga cabai merah di Gayo Lues di tingkat konsumen masih tergolong rendah. Hal ini disebabkan karena terbatasnya informasi dan transportasi karena jaraknya yang jauh dari wilayah perkotaan. Sementara konsumen yang paling banyak biasanya terdapat di daerah perkotaan seperti halnya Bireuen dan Kota Banda Aceh.

Variasi harga antar tempat tersebut disebabkan oleh beberapa faktor diantaranya:

a. Informasi pasar yang diperoleh petani sangat langka atau tidak seimbangnya informasi harga antar konsumen, pedagang dan petani.

b. Kesulitan pengangkutan antar daerah, karena keadaan infrastruktur yang masih dalam proses perbaikan menuju lintas Gayo Lues menyebabkan biaya angkut yang dikenakan cukup tinggi.

c. Petani masih berketergantungan terhadap pedagang, karena kurangnya modal yang dimiliki petani menyebabkan petani harus meminjam modal dari pedagang, dengan syarat petani harus menjual selurruh hasil produksinya kepada pedagang tersebut, meskipun harga yang dibayar oleh pedagang relatif rendah.

d. Keadaan pasar cabai merah yang oligopsonistik (dua atau lebih pelaku usaha menguasai penerimaan pasokan atau menjadi pembeli tunggal atas barang dan /atau jasa dalam suatu pasar komoditas), banyaknya petani yang memproduksi cabai merah dengan beberapa pedagang yang memasok cabai merah menyebabkan keadaan pasar yang tidak berjalan secara efisien. Hal ini dikarenakan pedagang perantara yang menguasi pasar selalu ingin memperoleh keuntungan yang setinggi-tingginya tanpa memikirkan berapa jumlah harga yang dibayarkannya kepada petani. 
Dalam memasarkan cabai merah, pedagang perantara mengumpulkan cabai merah langsung ke lokasi dimana petani tersebut membudidayakan cabai merah untuk dijual kembali kepada konsumen lokal maupun dijual ke luar daerah. Ketika hasil panennya sedikit, petani langsung menjualnya ke pasar konsumen. Namun masalah harga tetap mengikuti dan mengacu pada harga yang di tetapkan oleh pedagang perantara. Pada saat panen raya hasil produksi cabai merah melimpah dan petani menjual hasil produksinya kepada pedagang perantara meskipun harga yang ditetapkan sangat rendah hingga dibawah biaya produksi yang dikeluarkan oleh petani.

Dalam kondisi seperti ini pedagang perantara tetap dapat memperoleh keuntungan dengan memasarkan cabai merah keluar daerah yang menawarkan harga yang lebih tinggi dibandingkan harga yang ada di Gayo Lues, karena biaya yang dikeluarkan oleh pedagang lebih sedikit dibandingkan biaya produksinya. Disisi lain petani lebih memilih membiarkan cabai merahnya masak di batang, karena harga yang diterima petani tidak sebanding dengan ongkos panen yang harus di keluarkan oleh petani, belum lagi ongkos produksinya yang juga tinggi. Hal inilah yang menyebabkan turunnya minat petani cabai untuk memproduksi cabai merah pada periode selanjutnya. Selain itu, petani melakukan usahataninya tidak didasarkan pada peluang pasar, maupun permintaan pasar melainkan karena usahatani yang diusahakan secara turun temurun.

\section{Variasi Harga Menurut Waktu}

Stabilisasi harga cabai merah menjadi salah satu permasalahan perekonomian masyarakat petani cabai di Gayo Lues karena fluktuasi harga cabai merah yang terjadi secara terus-menerus sepanjang tahun. Pada saat harga cabai merah merosot turun akan menyebabkan menurunnya minat petani untuk mengusahakannya. Beberapa periode kedepannya produksi akan turun dan harga cabai merah berangsur- angsur naik. Hal ini juga berdampak terhadap daya beli konsumen yang tingkat kesejahteraannya rendah dan menyebabkan kenaikan inflasi.

Perubahan harga cabai merah juga dapat mempengaruhi perilaku pedagang untuk meningkatkan harga sayuran lainnya yang berhubungan dengan cabai merah. Peningkatan dan penurunan harga yang terjadi secara berulang dapat menimbulkan ketidak setabilan harga. Berikut adalah perkembangan harga rata-rata bulanan cabai merah di Kabupaten Gayo Lues beberapa tahun terakhir.

Dari Gambar 3 menunjukkan bahwa perkembangan harga petani dan eceran cabai merah di Gayo Lues periode bulan Januari 2014 - Desember 2017 memiliki kecenderungan yang berfluktuasi. Dalam satu tahun terdapat rata-rata harga memiliki pola yang teratur. Pada awal tahun harga mengalami kecendrungan menurun hingga pertengahan tahun dan akan kembali meningkat menjelang akhir tahun. Ketika perubahan harga terjadi yang mana sebelumnya Rp.76.250/Kg dan sangat meresahkan konsumen. Hal ini sangat meningkatkan minat petani cabai merah untuk meningkatkan produksinya. Namun ketika produksi meningkat dengan keadaan musim panen yang sama di setiap daerahnya menyebabkan pedagang perantara dengan modal terbatas merasa kewalahan menampung semua produksi dari petani sementara persediaan yang ada di pasar sangat banyak namun tidak bisa disimpan dalam waktu yang lama. Harga cabai merah berangsur-angsur merosot turun hingga $\mathrm{Rp} 2.000,00 / \mathrm{Kg}$. Penurunan harga cabai juga berpengaruh pada pengurangan area lahan budidaya. Karena pada dasarnya lahan yang digunakan oleh petani cabai adalah lahan persawahan. 


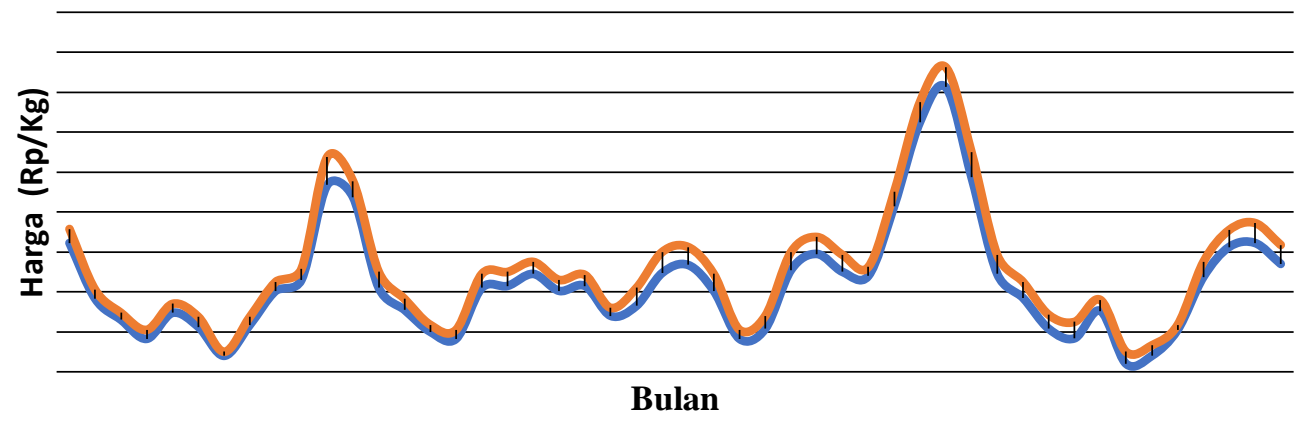

Harga di Petani ( $\mathrm{Rp} / \mathrm{Kg})$

Harga di pengecer $(\mathrm{Rp} / \mathrm{Kg})$

Sumber : Dinas Perdagangan Kabupaten Gayo Lues (2018), data diolah

Gambar 3. Perkembangan Harga Rata-rata Bulanan Cabai Merah di Kabupaten Gayo Lues Periode Januari 2014 - Desember 2017

Berdasarkan analisis variasi harga yang dilakukan pada harga rata-rata bulanan cabai merah di tingkat petani dan pengecer selama periode Januari 2014 - Desember 2017 menunjukkan pola pergerakan yang berfluktuasi. Hasil dari rata-rata nilai koefisien variasi harga cabai merah tahun 2014-2017 (Gambar 5), dapat dilihat bahwa fluktuasi harga cabai merah di Kabupaten Gayo Lues di tingkat petani dan 'pengecer adalah tinggi dan tidak stabil berdasarkan kriteria Kemendag yaitu di atas 9\% yang ditunjukkan dengan nilai rata-rata koefisen variasi sebesar 15,34\% dan 11,64\%. Adapun hasil analisis koefisien variasi harga cabai merah di Gayo Lues secara lengkap dapat dilihat pada gambar berikut.

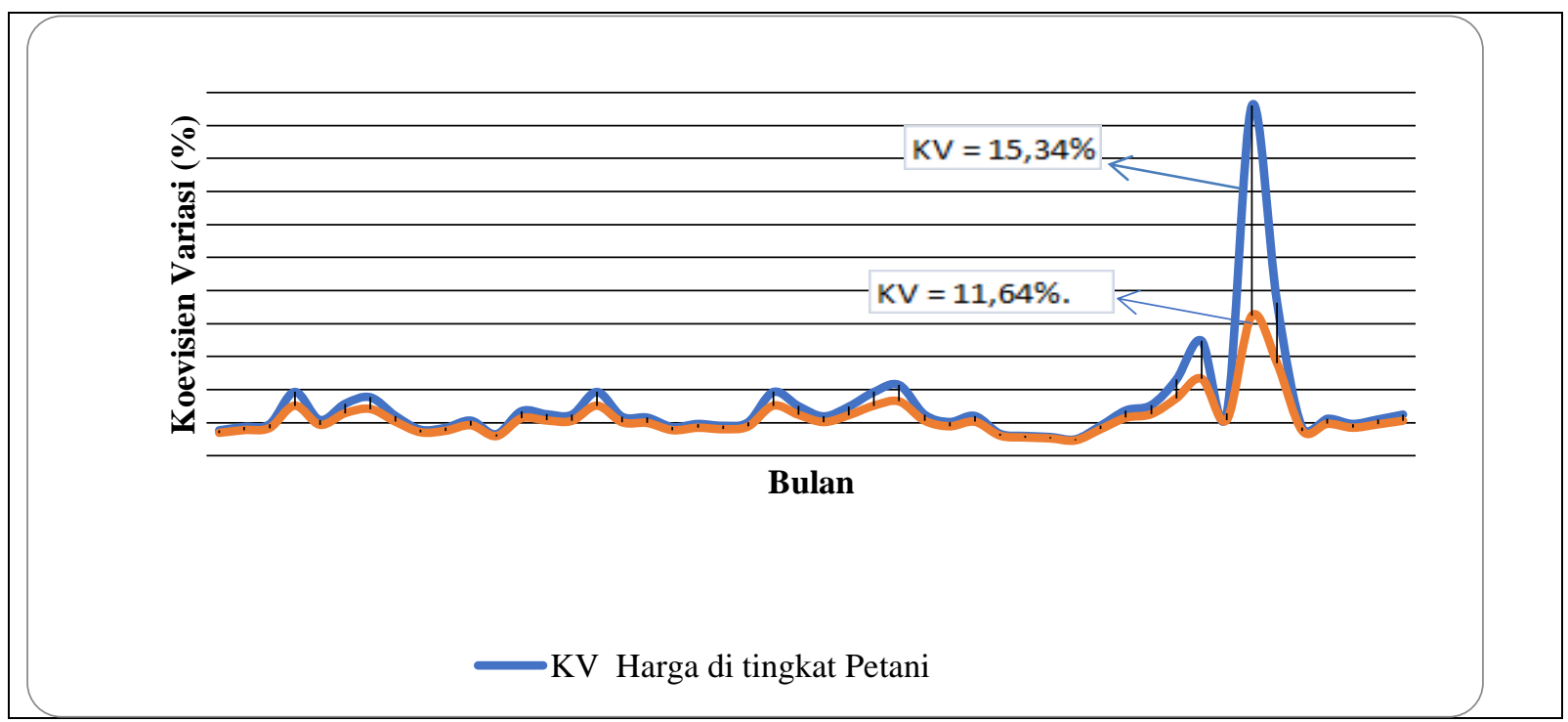

Sumber : Dinas Perdagangan Kab. Gayo Lues (2018), data diolah

Gambar 4. Koefisien Variasi (KV) Harga Cabai Merah di Tingkat Petani dan Pengecer di Kabupaten Gayo Lues Periode Januari 2014 - Desember 2017

Pada Gambar 4. dapat dilihat bahwa koefisien variasi tertinggi terjadi pada bulan juni 2017 yang mencapai 106,07\% di tingkat petani dan 42,43\% di tingkat pengecer disusul pada 
bulan juli yaitu $46,40 \%$ di tingkat petani dan $28,02 \%$ di tingkat pengecer dan selanjutnya kembali menurun. Padahal pada beberapa bulan sebelumnya pergerakan rata- rata koefisien variasinya cukup stabil karena dibawah 9\%. Dari gambar tersebut juga dapat kita lihat bahwa adanya variasi harga yang terjadi secara berulang dalam jangka waktu tertentu yang disebut sebagai variasi siklus. Variasi harga yang tinggi ini terjadi ketika cabai merah panen raya di Kabupaten Gayo Lues maupun beberapa daerah lainnya. Sehingga persediaan cabai merah di pasaran sangat bayak namun dalam jangka pendek permintaan konsumen cendrung tetap. Sehingga harga cabai merah mengalami penurunan hingga pada titik terendah yakni Rp $2.000,00 / \mathrm{Kg}$.

Penelitian ini sejalan dengan hasil penelitian Sandra et,al (2012), yang menyatakan bahwa harga komoditas cabai merah kriting adalah sangat berfluktuasi. Nilai koefisien variasi di daerah konsumen lebih kecil dibandingkan nilai koefisien variasi di daerah produsen (KV Konsumen 42,35 \% < KV Produsen 64,41 \%). Hal ini menunjukkan bahwa harga cabai merah keriting di tingkat konsumen relatif stabil dibandingkan dengan harga di tingkat petani, dengan kata lain bahwa harga cabai merah keriting di tingkat petani lebih berfluktuasi dari pada harga di tingkat konsumen.

Nuraeni et,al (2015), juga mebyatakan bahwa tingkat fluktuasi harga tanaman hortilkultura dari jenis sayuran lebih tinggi di tingkat petani dibandingkan di tingkat konsumen, misalnya saja tingkat fluktuasi harga bawang merah di tingkat produsen, grosir dan eceran adalah tinggi dan tidak stabil hal ini dapat dilihat dari perbandingan nilai koefisien variasinya (KV produsen 24,15\% > KV konsumen 21,15\%) fluktuasi harga bawang merah ini dikatakan tinggi dan tidak stabil berdasarkan kriteria Kemendag, karena berada diatas $9 \%$.

Variasi harga yang diakibatkan oleh pergeseran keseimbangan permintaan dan penawaran ini terjadi ketika penawaran lebih tinggi dari permintaan menyebabkan harga menjadi turun ataupun sebaliknya. Untuk menciptakan pasar yang kompetitif memang memerlukan adanya fluktuasi harga. Karena tanpa adanya fluktuasi harga fungsi pasar tidak dapat berjalan dengan baik, karena para petani produsen tidak akan terangsang untuk meningkatkan produksinya, dan produksi tidak akan mengalami peningkatan. Perubahan dari harga akan menjadi masalah apabila harga melonjak sangat tinggi karena stok produk mengalami kelangkaan, dan tidak dapat diprediksi yang nantinya akan menciptakan suatu ketidakpastian yang mampu meningkatkan risiko bagi produsen, pedagang, konsumen, dan tentu juga pemerintah. Perubahan dari harga yang tidak merespon kinerja pasar akan menciptakan permasalahan baru, yaitu dapat menciptakan kesalahan dalam pengambilan kebijakan oleh pemerintah (Kemendag, 2010).

\section{Integrasi Pasar Vertikal}

\section{Uji Stasioneritas Data}

Uji stasioneritas yang digunakan adalah uji ADF (Augmented Dickey Fuller) dengan menggunakan taraf nyata 5\%. Hasil uji stasioneritas pada variabel harga cabai merah di pedagang pengecer dan harga di tingkat petani di Gayo Lues adalah sebagai berikut: Tabel 1. Hasil Uji Stasioneritas

\begin{tabular}{llccccc}
\hline \multirow{2}{*}{ Variabel } & ADF t- & \multicolumn{2}{c}{ Nilai Kritis MacKinnon } & Prob & Ket. \\
\cline { 3 - 5 } & Statistik & $\mathbf{1 \%}$ & $\mathbf{5 \%}$ & $\mathbf{1 0 \%}$ & & \\
\hline Harga di & -4.190154 & -3.581 .1 & -2.926 .6 & -2.601 .4 & 0.0018 & Stasioner \\
Pengecer(PF) & & & & & & \\
Harga di Petani (PR) & -4.157239 & -3.581 .1 & -2.926 .6 & -2.601 .4 & 0.0020 & Stasioner \\
\hline
\end{tabular}

Sumber: Data sekunder (diolah), 2018

Pada tabel 1. Menjelaskan bahwa t-Statistik lebih kecil dari pada nilai kritis Mackinnon pata tingkat level dengan taraf kepercayaan 1\%,5\%, dan 10\%. Variabel harga eceran dan harga

Analisis Variasi Harga dan Integrasi Pasar Vertikal Cabai Merah di Kabupaten Gayo Lues 
di tingkat petani ditunjukkan oleh nilai ( $\mathrm{t}$ statistik -4.190154) dan (t statistik -4.157239) < nilai kritis $(1 \%=-3.581 .152),(5 \%=-2.926 .622),(10 \%=-2.601 .424)$. Maka terima Ha. Hal ini bermakna bahwa kedua variabel tersebut telah stasioner pada derajat integrasi 0 , sehingga data yang digunakan pada uji selanjutnya adalah data original.

\section{Uji Lag Optimal}

Estimasi VECM sangat peka terhadap panjang lag yang digunakan. Untuk mengetahui lag yang akan digunakan maka dilakukan uji Lag optimal. Berikut hasil uji Lag optimal yang disajikan pada Tabel 2.

Tabel 2. Hasil Uji Lag Optimal

\begin{tabular}{cclllll}
\hline Lag & LogL & LR & FPE & AIC & SC & HQ \\
\hline 0 & -0.503784 & 0.063921 & 0.003911 & 0.131778 & 0.217967 & 0.162443 \\
1 & 13.37209 & 25.56082 & 0.002327 & -0.388005 & $-0.12943^{*}$ & -0.296009 \\
2 & 19.11588 & $9.976066^{*}$ & $0.002128^{*}$ & $-0.47978^{*}$ & -0.048840 & $-0.32645^{*}$ \\
3 & 20.06345 & 1.546035 & 0.002513 & -0.319129 & 0.284192 & -0.104472 \\
4 & 22.10980 & 3.123363 & 0.002812 & -0.216305 & 0.559394 & 0.059683 \\
\hline
\end{tabular}

Sumber: Data sekunder (diolah), 2018

Penentuan jumlah lag (ordo) dilakukan dengan melihat tanda (*) yang paling banyak pada baris jumlah Lag disetiap variabelnya. Dari Tabel 2. dapat dilihat bahwa Lag optimal yang diperoleh adalah 2 dengan demikian pada tahap pengujian selanjutnya panjang Lag yang di gunakan adalah 2. Selanjutnya akan dilakukan uji kointegrasi Johansen untuk mengetahui hubungan jangka panjang yang terjadi pada masing-masing level pemasaran.

\section{Uji Kointegrasi Johansen}

Hasil uji Kointegrasi Johansen menunjukkan adanya dua persamaan yang terkointegrasi yang di tunjukkan oleh nilai trace statistic lebih besar dari pada nilai $t$-statistik, dan pada max eigen value terdapat satu persamaan yang terkointegrasi maka dapat disimpulkan bahwa kedua variabel tersebut terkointegrasi pada taraf nyata 5\%. Hasil uji kointegrasi secara lengkap dapat dilihat pada tabel berikut:

Tabel 3. Hasil Uji Kointegrasi Johansen

\begin{tabular}{ccccc}
\hline $\begin{array}{c}\text { Hypothesized } \\
\text { No. of CE(s) }\end{array}$ & Eigenvalue & $\begin{array}{c}\text { Trace } \\
\text { Statistic }\end{array}$ & $\begin{array}{c}0.05 \\
\text { Critical Value }\end{array}$ & Prob.** \\
\hline None $*$ & 0.206121 & 18.66115 & 15.49471 & 0.0161 \\
At most $1 *$ & 0.167954 & 8.274056 & 3.841466 & 0.0040 \\
& & & & \\
\hline Hypothesized & & Max-Eigen & 0.05 & \\
No. of CE(s) & Eigenvalue & Statistic & Critical Value & Prob.** \\
\hline None & 0.206121 & 10.38710 & 14.26460 & 0.1877 \\
At most $1 *$ & 0.167954 & 8.274056 & 3.841466 & 0.0040 \\
\hline
\end{tabular}

Sumber: Data sekunder (diolah), 2018

Pada Tabel 3. dapat dilihat bahwa berdasarkan pada pengujian trace statistic menunjukkan terdapat dua persamaan yang terkointegrasi pada taraf nyata 0,05 , dengan nilai T-statistik lebih besar dari Critical Value 5\%, yaitu 18.66115 > 15.49471. Maka terima $\mathrm{H}_{\mathrm{a}}$ dan tolak $\mathrm{H}_{0}$, Hal ini berarti bahwa antara pasar di tingkat petani dengan pasar di tingkat pengecer terdapat hubungan kointegrasi. Sehingga dapat disimpulkan bahwa pasar cabai merah di tingkat petani dengan pasar di tingkat pengecer di Kabupeten Gayo Lues terdapat hubungan kointegrasi jangka panjang. 


\section{Uji Kausalitas}

Uji kausalitas bertujuan untuk mengetahui hubungan antara variabel harga cabai merah di tingkat petani dan di tingkat pengecer dengan metode Causality Granger Test. Hasil uji kausalitas dengan tarafnyata 5\% dapat dilihat pada tabel berikut:

Tabel 4. Hasil Uji Kausalitas

\begin{tabular}{lccl}
\hline \hline Null Hypothesis: & Obs & F-Statistic & Prob. \\
\hline \hline PF does not Granger Cause PR & 46 & 0.54080 & 0.5864 \\
PR does not Granger Cause PF & & 1.13548 & 0.3312 \\
\hline \hline
\end{tabular}

Sumber: Data sekunder (diolah), 2018

Dari tabel 4. dapat dilihat bahwa nilai probabilitas dari kedua variabel tersebut lebih besar dari pada nilai taraf nyata, yaitu $0,586>0,05$, maka terima $\mathrm{H}_{0}$. Hal ini menjelaskan bahwa antara variabel PF (harga di tingkat petani) dan PR (harga di tingkat pengecer) tidak terdapat hubungan kausalitas. Tidak adanya hubungan kausalitas ini menjelakan bahwa antara PF dan PR tidak memiliki hubungan yang berketergantungan yang disebabkan karena sistem distribusi cabai merah yang masih buruk dan penyaluran informasi mengenai harga di tingkat pengecer ke petani masih kurang.

\section{Uji Vector Error Correction Model (VECM)}

Untuk mengetahui seberapa besar perubahan harga cabai merah di tingkat pengecer dapat diikuti perubahan harga cabai merah di tingkat petani dalam jangka panjang maka dapat dilihat pada tabel uji VECM sebagai berikut:

Tabel 5. Hasil Estimasi VECM Jangka Panjang

\begin{tabular}{llll}
\hline Variabel & Koefisien & Standar Error & T statistic \\
\hline $\operatorname{PF}(-1)$ & 1.000000 & & \\
$\mathrm{PR}(-1)$ & -0.974804 & 0.01689 & -57.7236 \\
$\mathrm{C}$ & 2.781325 & & \\
\hline
\end{tabular}

Sumber: Data sekunder (diolah), 2018

Keterangan:

$\mathrm{C} \quad=$ Konstanta

$\mathrm{PF}(-1)=$ Perubahan harga jual cabai merah di tingkat petani pada satu periode sebelumnya

PR(-1) = Perubahan harga jual cabai merah di tingkat pengecer pada satu periode sebelumnya

Berdasarkan Tabel 5. terbentuk satu persamaan hubungan jangka panjang yang menunjukkan antara variabel PF dan PR memiliki hubungan negatif yang dapan dilihat seperti pada persamaan berikut:

$\mathbf{P F}=2.781325-0.974804 \mathbf{P R}(-1)$

Dari persamaan diatas dapat diinterpretasikan bahwa tanpa adanya perubahan harga di tingkat pengecer pada periode sebelumnya, harga cabai di tingkat petani adalah Rp 2.781,00. Sementara kenaikan harga jual cabai merah sebesar Rp 1.000,00 di tingkat pengecer pada satu periode sebelumnya akan menyebabkan penurunan harga jual cabai merah di tingkat petani sebesar Rp. 974,00 pada saat ini. Hal ini dikarenakan pada saat harga cabai merah di tingkat pengecer naik pada satu periode sebelumnya akan menyebabkan petani produsen meningkatkan jumlah produksinya pada saat ini sehingga harga cabai merah di tingkat petani saat ini akan mengalami penurunan, begitu pula sebaliknya. Ketika harga cabai merah di tingkat pengecer turun pada satu periode sebelumnya akan menyebabkan petani produsen mengurangi jumlah produksinya pada saat ini sehingga harga cabai merah di tingkat petani saat ini akan kembali 
naik karena terjadinya kekurangan stok cabai merah di pasaran. Hal ini menjelaskan bahwa terdapat hubungan integrasi jangka panjang antara petani dan pengecer namun masih relatif lemah.

Seperti yang telah di jelaskan sebelumnya dalam analisis variasi harga bahwa keterlambatan waktu dalam meningkatkan produksi cabai merah dapat merubah ketepatan dalam memprediksikan pergeseran permintaan dan penawaran sehingga bila penawaran cabai merah tidak bertambah, harga akan tetap tinggi karena elastisitas penawaran hasil pertanian pada umumnya kecil sekali. Penawaran hanya dapat bertambah sampai pada batas tertentu, sedangkan permintaan terus bertambah. Pedagang perantara dapat menambah penawaran dengan mengeluarkan persediaan (stock), tetapi juga hanya sampai batas tertentu saja, dan harga barang tetap tinggi. Petani produsen sendiri tidak dapat bebas memperbesar produksi, tetapi hanya sampai batas tertentu hingga harga stabil dan dapat memberikan penawaran lebih besar hingga harga akan turun. Adapun hasil estimasi hubungan jangka pendek antara variabel harga di tingkat petani dan harga di tingkat pedagang pengecer dapat dilihat pada tabel berikut:

Tabel 6. Hasil Estimasi ECM Hubungan Jangka Pendek

\begin{tabular}{ccc}
\hline Error Correction: & $\mathrm{D}(\mathrm{PF})$ & $\mathrm{D}(\mathrm{PR})$ \\
\hline ECT1 & 4.736471 & 5.523294 \\
Standar error & $(1.85855)$ & $(1.98228)$ \\
T statisti & {$[2.54847]$} & {$[2.78634]$} \\
& & \\
$\mathrm{D}(\mathrm{PF}(-1))$ & -2.458736 & -2.481541 \\
& $(2.02055)$ & {$[2.15506)$} \\
& {$[-1.21686]$} & {$[-1.15149]$} \\
$\mathrm{D}(\mathrm{PF}(-2))$ & 0.923341 & 0.962418 \\
& $(1.62688)$ & $(1.73518)$ \\
& {$[0.56755]$} & {$[0.55465]$} \\
$\mathrm{D}(\mathrm{PR}(-1))$ & 2.723109 & 2.758007 \\
& $(1.88227)$ & $(2.00757)$ \\
& {$[1.44672]$} & {$[1.37380]$} \\
$\mathrm{D}(\mathrm{PR}(-2))$ & -1.101688 & -1.119555 \\
& $(1.54808)$ & $(1.65113)$ \\
& {$[-0.71165]$} & {$[-0.67805]$} \\
$\mathrm{C}$ & 0.076848 & 0.138389 \\
& $(1.26645)$ & $(1.35075)$ \\
& {$[0.06068]$} & {$[0.10245]$} \\
\hline
\end{tabular}

Sumber: Data sekunder (diolah), 2018

Hasil estimasi hubungan integrasi jangka pendek yang menggambarkan perubahan harga di tingkat petani dipengaruhi oleh hubungan jangka panjang antara petani dan pengecer. Dalam jangka pendek perubahan harga di tingkat petani satu periode sebelumnya dan harga di tingkat pengecer dua periode sebelumnya berpengaruh negatif terhadap perubahan harga di tingkat petani saat ini. Hal ini mengindikasikan bahwa dalam jangka pendek antara pasar di tingkat petani dengan pasar di tingkat pengecer terdapat hubungan integrasi yang masih relatif lemah. Hubungan integrasi tersebut dapat dilihat dari persamaan yang terbentuk dari hasil estimasi ECM pada Tabel 6. yakni sebagai berikut: 


\section{$\mathrm{D}(\mathbf{P F})=0.076848-2.458736 \mathrm{D}(\mathrm{PF}(-1))+0.923341 \mathrm{D}(\mathrm{PF}(-2))+2.723109 \mathrm{D}(\mathbf{P R}(-1)-$ $1.101688 \mathrm{D}(\mathbf{P R}(-2))$}

Persamaan tersebut dapat diintepretasikan bahwa tanpa adanya perubahan harga di tingkat pedagang pengecer pada periode sebelumnya harga di tingkat petani adalah $\mathrm{Rp} 77,00$. Kenaikan harga cabai merah di tingkat petani sebesar Rp 1000,00 satu periode sebelumnya akan menurunkan harga cabai merah di tingkat petani saat ini sebesar Rp 2.458,00. Kenaikan harga jual cabai merah di tingkat petani pada dua periode sebelumnya sebesar Rp. 1,000.00 akan menaikkan harga jual cabai merah di tingkat petani saat ini sebesar Rp 923,00. Kenaikan harga jual cabai merah di tingkat pedagang pengecer pada satu periode sebelumnya sebesar Rp. 1,000.00 akan menaikkan harga jual cabai merah di tingkat petani saat ini sebesar Rp 2.723,00. Kenaikan harga jual cabai merah di tingkat pedagang pengecer pada dua periode sebelumnya sebesar Rp. 1,000.00 akan menurunkan harga jual cabai merah besar di tingkat petani saat ini sebesar Rp. 1.101,00.

Hasil dari penelitian ini menunjukkan kedua pasar tersebut memiliki hubungan keseimbangan dan keterpaduan yang masih relatif lemah dalam jangka pendek. Keterpaduan antara pasar di tingkat petani dan pengecer tersebut ditunjukkan oleh nilai koefisien yang bertanda negatif. Menurut Baffes dan Bruce, dalam Nuraeni et al (2015). Integrasi pasar akan tercapai jika terdapat informasi pasar yang sama memadai disalurkan dengan cepat ke pasar lain dan memiliki hubungan yang positif antara harganya di pasar yang berbeda.

Perubahan harga dan pasar yang kurang terintegrasi seperti ini terjadi karena adanya pergeseran permintaan dan pemawaran. Produksi cabai merah umumnya bersifat musiman sehingga menyebabkan penawaran cabai merah di pasaran tidak menentu. Ketika penawaran sedikit dan terjadi kelangkaan akan menyebabkan harga cabai merah tinggi dan hal ini sangat meningkatkan minat petani untuk meningkatkan produksinya. Sehingga pada periode selanjutnya persediaan cabai merah di pasar akan berangsur-angsur bertambah yang menyebabkan harga cabai merah akan stabil hingga batas waktu tertentu saja hingga terjadi panen raya dan harga akan kembali turun karena persediaan cabai merah di pasar melimpah. Hal ini terjadi secara berulang dan didukung oleh kebiasaan petani cabai di Gayo Lues dalam peningkatan produksi dilakukan pada saat harga tinggi tanpa memprediksi harga dalam waktu jangka panjang.

Hal ini sejalan dengan yang dikemukakan Nasruddin dan Ahmad (2010), bahwa harga yang tidak stabil dan pasar kurang terintegrasi terjadi karena adanya pergeseran fungsi penawaran dan permintaan atau pun faktor luar seperti adanya siklus bisnis, kekeringan, bencana banjir, atau serangan hama dan penyakit. Kenaikan harga bagi produsen merupakan perangsang untuk meningkatkan produksi, tetapi sejak produsen menerima rangsangan sampai produksi bertambah terdapat kelambatan waktu ( Time lag) sehingga bila permintaan tidak berubah harga akan tetap tinggi karena elastisitas penawaran hasil pertanian pada umumnya kecil sekali. Penawaran hanya dapat bertambah sampai pada batas tertentu, sedangkan permintaan terus bertambah. Tengkulak atau pedagang perantara dapat menambah penawaran dengan mengeluarkan persediaan (stock), tetapi juga hanya sampai batas tertentu saja dan harga barang tetap tinggi. Produsen sendiri tidak dapat bebas memperbesar produksi, tetapi hanya sampai batas tertentu hingga harga stabil, serta dapat memberikan penawaran lebih besar hingga harga akan turun. Dari keadaan tersebutlah terjadi siklus harga.

Hasil dari penelitian ini sama dengan penelitian yang dilakukan oleh Idrus (2013), bahwa integrasi pasar vertikal relatif masih lemah untuk komoditi hortikultura cabai merah keriting, tomat, wortel, kembang kol, alpokat dan jeruk siam di kabupaten Aceh Tengah. Hal ini dapat terjadi karena keterbatasan petani produsen cabai merah dalam mengakses pasar dan mengikuti perputaran harga di pasar eceran, karena jarak lokasi budidaya dengan pusat pasar 
yang cukup jauh dan keterbatasan transportasi yang dimiliki petani. Sehingga petani menjual hasil produksinya kepada pedagang perantara.

Hasil uji ECM pada Tabel 6. menunjukkan bahwa koreksi kesalahan (Error Correction

Term ) pada harga di tingkat petani dan pedagang pengecer pada taraf nyata $5 \%$ yaitu masingmasing sebesar 4.736471 dan 5.523294. Nilai koefisien ECT ini mengindikasikan pentingnya hubungan kointegrasi jangka panjang pada proses pembentukan harga di masing-masing pasar. Nilai koefisien ECT tersebut juga menunjukkan bahwa penyesuaian harga di tingkat pengecer lebih cepat dari pada ditingkat petani dikarenakan nilai koefisien ECT di tingkat pengecer lebih besar dari nilai ECT di tingkat petani.

\section{Simpulan}

\section{SIMPULAN DAN SARAN}

Berdasarkan hasil penelitian yang telah dilakukan, maka dapat ditarik simpulan sebagai berikut:

1. Variasi harga cabai merah yang terjadi di antara petani dan pedagang pengecer adalah tinggi dan tidak stabil berdasarkan nilai kriteria Kemendag yang ditunjukkan oleh nilai rata-rata koefisien variasi sebesar 15,34\% di tingkat petani dan 11,64\% di tingkat pedagang pengecer

2. Analisis integrasi pasar vertikal cabai merah di Kabupaten Gayo Lues yang terjadi di antara petani dan pedagang pengecer menunjukkan bahwa pasar terintegrasi secara lemah baik Saran dalam jangka pendek maupun jangka panjang.

Berdasarkan hasil penelitian dan kesimpulan di atas maka penulis memberikan beberapa saran yang dapat dijadikan sebagai masukan dalam mewujudkan stabilitas harga dan pasar yang terintegrasi, antara lain:

1. Perlu dilakukan penanaman cabai merah secara bertahap, sehingga petani dapat melakukan penawaran secara berkelanjut, dengan demikian stabilitas harga di tingkat petani dan pasar konsumen akan lebih terkendali.

2. Pemerintah perlu memberikan intervensi terkait penyaluran informasi tentang harga cabai merah secara berkelanjutan, baik itu di media cetak, televisi, maupun media elektronik lainnya agar petani dan konsumen dapat mengetahui setiap perubahan harga cabai merah tersebut secara cepat dan tepat.

3 .

\section{DAFTAR PUSTAKA}

Badan Pusat Statistik. 2017. Aceh dalam Angka 2016. BPS. Aceh.

Badan Pusat Statistik. 2017. Kabupaten Gayo Lues dalam Angka 2016. BPS. Aceh.

Basuki, A.T. dan N. Prawoto. 2016. Analisis Regresi Dalam Penelitian. Ekonomi \& Bisnis. Edisi Pertama. Cetakan Pertama, Rajawali Pers.

BPTP Aceh. 2017. Rekapitulasi Harga Bulanan Sayuran di Aceh 2016. (Belum di Publikasi). Aceh.

Cahyaningsih, E. 2014. Analisis Integrasi Pasar Gula dalam Mendukung Stabilisasi Harga Gula. Artikel. Perum Bulog, Jalan Gatot Subroto Kav 49 Jakarta Selatan.

Dinas Perindustrian dan Perdagangan. 2017. Monev Harga Pangan dan Kebutuhan Pokok 2014-2017. Disperindag. Kabupaten Gayo Lues.

Eliza, D. Jusar. dan D. Bakce. 2017. Analisis Variasi Harga Beras di Provinsi Riau dan Daerah Pemasok. Jurnal Dinamika Pertanian Volume Xxxiii Nomor 2 Agustus 2017 (19-26).

Fazaria, D. A., Dedi B., H. dan Sahara. 2016. Analisis Integrasi Harga Lada di Pasar Domestik dan Internasional. Buletin Ilmiah Litbang Perdagangan, VOL.10 NO.2. 
Gujarati N. D. 2004. Basic Econometrics Fourth Edition. Mc Graw-Hill. New York.

Handayani, S. M. dan F. Minar. 2000. Integrasi Pasar Antar Wilayah dalam Pemasaran Ubi Kayu Daerah Yogyakarta. Penelitian Kelompok dalam Bidang Pertanian. UNS Press. Surakarta.

Haryanti, T. 2012. Analisis Perilaku Harga dalam Pemasaran Cabai Merah (Capsicum Annum L.) di Kabupaten Sragen. Skripsi. Jurusan Sosial Ekonomi Pertanian. Fakultas Pertanian. Universitas Salemba Empat.

Hasyim. 2017. Petani Gayo Lues Biarkan Tanaman Membusuk. Serambi Indonesia. Aceh.

Hendy, D. F. and K. Juselius. 2000. Explaining Co-integration Analysis: Part I, Energy Journal $21,44$.

Idrus, M. 2013. Analisis Integrasi Pasar Vertikal Beberapa Komoditi Hortikultura di Kabupaten Aceh Tengah. Skripsi. Jurusan Sosial Ekonomi Pertanian. Fakultas Pertanian Unsyiah. Banda Aceh.

Kementerian Perdagangan. 2010. Rencana Strategis Kementerian Perdagangan Periode 20102014. Kementerian Perdagangan. Jakarta.

Kustiari, R. 2017. Perilaku Harga dan Integrasi Pasar Bawang Merah di Indonesia. Jurnal Agro Ekonomi, Vol. 35 No. 2, Oktober 2017. Hal 77-87

Kusumaningsih A. 2015. Analisis Integrasi Vertikal Pasar Beras di Indonesia. Buletin Bisnis \& Manajemen Volume 01, No. 02, Agustus 2015

Mc Daniel, C. dan G. Roger. 1999. Riset Pemasaran Kontenporer. Salemba Empat . Jakarta.

Muslikh. 2000. Analisis Sistem Tataniaga Cabai Rawit Merah di DKI Jakarta (Studi kasus Pasar Kramat Jati, Pasar Jati Negara, dan Pasar Tanah Abang). Skripsi. Sosial Ekonomi Pertanian. IPB. Bogor.

Nasruddin, W. dan M. Ahmad. 2010. Modul Tataniaga Pertanian. Universitas Terbuka. Tangerang selatan

Nuraeni, D., R. Ardhiani dan Syafrial. 2015. Analisis Variasi Harga dan Integrasi Pasar Bawang Merah di Jawa Barat. Jurnal. Habitat, Volume 26(3).63-172.

Rachman, H. 2005. Metode Analisis Harga Pangan. Disampaikan pada Apresiasi Distribusi Pangan dan Harga Pangan oleh Badan Ketahanan Pangan. Departemen Pertanian, Bogor.

Rahmanto dan Budiman. 2012. Dimensi Oligopsonistik Pasar Domestik Cabai Merah. Pusat Penelitian dan Pengembangan Sosial Ekonomi Pertanian. Badan Litbang Departemen Pertanian, Bogor.

Rusydiana, A. S. 2009. Mekanisme Transmisi Syariah Pada Sistem Moneter Ganda di Indonesia. "Buletin Ekonomi dan Perbankan.hal 5.

Sandra, P. S. Asriani dan W. Rasyid. 2012. Perilaku Harga dan Keterpaduan Pasar Cabai Merah Keriting (Capsicum Annuum) di Provinsi Bengkulu. Jurnal Agrisep. Vol. 11 No. 2 Hal: $220-236$.

Santika, A. 2008. Agribisnis Cabai. Penebar Swadaya .Jakarta.

Shochrul, R.A.,W.S. Dyah., H.S. Rahmat dan R. P. Martha. 2011. Cara Cerdas Menguasai Eviews. Salemba Empat. Jakarta.

Simatupang, P. 1999. Industrialisasi Pertanian Sebagai Strategi Agribisnis dan Pembangunan Pertanian. Pusat Penelitan Sosial Ekonomi Pertanian. Bogor.

Sitorus, E. 2007. Keterpaduan Pasar Tuna Segar Benoa/ Bali, Indonesia dan Pasar Central Tuna Tokyo, Jepang. Jurnal SOCA 7(1): 36-43.

Soekartawi. 2001. Agribisnis Teori dan Aplikasinya. PT. Raja Grafindo Persada. Jakarta.

Sudiyono,A. 2002. Pemasaran Pertanian. UMM Press. Malang.

Analisis Variasi Harga dan Integrasi Pasar Vertikal Cabai Merah di Kabupaten Gayo Lues

(Wan Jumiana, Edy Marsudi, Azhar) 
Suharyadi dan Purwanto. 2003. Statistika: Untuk Ekonomi dan Keuangan Modern. Salemba Empat. Jakarta.

Susanawati, Jamhari, Masyhuri dan Dwidjono. 2015. Integrasi Pasar Bawang Merah di Kabupaten Nganjuk (Pendekatan Kointegrasi Engle-Granger). Jurnal AGRARIS Vol.I No.1

Widadie, F. dan S. Adi. 2012. Model Ekonomi Perberasan: Analisis Integrasi Pasar dan Simulasi Kebijakan Harga. Jurnal SEPA : Vol. 8 No.2. Hal. 51 - 182 .

Winardi. 1992. Harga dan Penetapan Harga dalam Bidang Pemasaran. Edisi Revisi. PT. Citra Aditya Cipta Bakti. Bandung. 